\title{
Why Labour Is Not Different
}

\author{
Gerald T. Garvey
}

T The notion that the labour market and the employment relationship are fundamentally different from other markets and contractual relationships underpins a great deal of government interference in the lives of Australians. The centralised approach to wage determination, the privileged status of trade unions, and recent proposals that purport to ease the burden of the long-term unemployed are all based on the idea that many of us lose the ability to perceive and protect our own interests when we are on the seller side of the labour market. Short shrift is given to the basic economic insight that labour-market outcomes for all parties can be improved simply by removing the huge number of policies that impede the formation of employment relationships on terms that are acceptable to both buyer (employer) and seller (employee).

Why do labour-market policies give so little weight to the goal of allowing and encouraging voluntary exchange between consenting adults? The standard argument is that the assumptions of economic theory are so drastically at odds with the realities of the labour market that economists have nothing to contribute. It is widely believed that the suspension of awards, monopoly unions, penalty rates, and 'comparative wage justice' would not move us closer to the ideal world of economics textbooks, in which employers and employees contribute to one another's future prosperity. Rather, we would have, in the words of Paul Keating, Australia's Prime Minister, 'a return to the dark ages of master and servant . . a matter of taking the bosses' conditions or taking the sack' (Australian Financial Review, 15 October 1992, p.15).

The reality is that although many labour markets differ substantially from markets for stylised commodities, they do not do so in a way that invalidates basic economic principles or policy prescriptions. The benefits of free choice in the terms and conditions of employment are, if anything, greater than those we enjoy in more mundane areas such as the supply and demand of foodstuffs, lawn mowers, or housing.

\section{The Standard View of Labour Markets}

A clear statement of the standard view that labour is somehow different from other economic goods, and that the differences justify the Australian approach to labour-

Gerald Garvey is Senior Lecturer in Economics in the Faculty of Economics and Commerce at the Australian National University. 
market regulation, is provided by McCallum (1993:297) in his review of Brook (1990):

Brook sets out her free market model for dealing with labour relations. The marketplace should govern the free exchange of labour, as well as decisions about investment and the purchasing of goods and services. Employment contracts should be between individual employees and their employers. Any laws that are perceived as giving trade unions advantages must be repealed. As I believe that the marketplace for human capital cannot be equated with the market for investments and for goods and services, I disagree with her approach. . . For those like myself who argue that collective labour law is essential in a capitalist society as the best means of equalising employee power, this book shows that it is time to defend the collectivist elements of our labour laws.

This passage exhibits a fundamental ignorance of the basic principles behind the market for investments, goods, and services as well as that for labour. Allmarkets involve human beings. All exchanges within markets enhance the well-being of all parties involved, in their own judgment. Forming and maintaining a long-term employment relationship no doubt involves a great deal of uncertainty and complexity, and has a large impact on the material and psychological welfare of the parties involved. So it is with the provision of venture capital or the purchase of a home. The participants in these markets also experience the anxiety, hope, trust, disappointment, and so forth that characterise all important social interactions. And every economic interaction provides at least expected benefits for both sides. Even the profits that the 'capitalist' is often portrayed as expropriating from workers, in fact accrue to people who entrusted the fruits of their own past labour to the enterprise.

The preceding discussion is based on the most basic economic principles. As Judith Sloan (1994) observes, modern labour market research goes well beyond the textbook conception of the labour market as involving once-off deals between faceless parties. The research also highlights the importance of allowing precisely the sort of contractual freedom that McCallum disparages. The message that individual free choice is the best policy for both sides of the labour market is amplified by recognising the uncertainties, complexities, and long-term nature of many employment relationships. It is the collectivist approach that understates the complexities, uncertainties, and importance of the labour exchange process, and that facilitates the exercise of capricious power over the fate of individuals.

The following sections examine, first, several arguments for regarding labour as different, and second, some policies that flow from these arguments. 


\section{The 'Humanistic' Argument for the Uniqueness of Labour}

Perhaps the most fundamental argument for the uniqueness of labour is that a person's job is a critical determinant of his or her psychological as well as financial wellbeing. This argument holds that 'good jobs' are vital to achieving 'self-esteem' and 'empowerment'. Whatever these terms mean, it is hard to imagine how they are enhanced by labour-market policies that dictate the terms on which one may accept a job and often the methods one may use once on the job.

It is undeniable that unemployment and/or unpleasant, low-paid jobs are undesirable for the individuals involved and perhaps for society at large. But this observation has special implications for labour-market policy only if a person's psychological and financial well-being is not affected by any other item he or she might consume or sell. One's home, automobile, investments, child-care arrangements, holidays, and so forth would have to be mere 'commodities' that exist only to sustain biological life; and the quality of the goods and of the relations one has with the sellers of these goods, for example, would have to be a matter of pure indifference. In fact, the economic value of anything is solely determined by the benefits that it provides for people. The value of a motor vehicle can be stated in terms of 'empowerment' (in concrete terms, it delivers the ability to travel, to take romantic interludes, to take one's children to see their relatives, and so forth).

Suppose we took seriously the logic that we must impose heavy-handed regulations on all markets that, like the labour market, have a vast potential to affect the welfare of the buyers and sellers involved. Since, as already established, motor-cars are an important good, we should have a centralised automobile tribunal that specifies exactly the type of motor-car that each type of person shall have. Or we might take a more laissez-faire approach and specify minimum prices that sellers must demand (in order to protect them from receiving less than the equivalent of the minimum wage). As experience in the ex-communist' world showed, such systems tend to provide the population with very few automobiles of very low quality, allocated to those with inside privileges. This is a disturbingly accurate description of many areas of the Australian job market.

Nor is the labour market different in involving interpersonal relations. Unpleasant fellow workers or superiors certainly may compromise one's self-esteem; but so can a tradesman who highlights one's own inadequate knowledge of plumbing or mechanics. Presumably no one would suggest that the ideal way to ensure against such personal pain is to force all those who use tradesmen to join a single union with the ability to call out one's fellow consumers on a general strike. The idea that no one should be able to contract to have leaky taps fixed or motorcars repaired until the individual grievance was resolved is no less absurd in the context of labour markets. It is merely more familiar. 


\section{The 'High Moral Ground' Argument}

Closely related to the humanistic argument is the notion that working conditions agreed to by employers and employees are somehow morally inferior to those mandated by a tribunal. Shann (1930:375) describes the genesis of the Australian wage-fixing system in just such terms: 'In 1907, a Judge of the High Court of Australia, presiding over a Federal Arbitration Court, took high moral ground in claiming for the workers a wage independent of supply and demand' (emphasis added).

This statement relies on a depersonalised vision of the market as involving 'merely' supply and demand. When we recall that suppliers and demanders are in fact people looking to better their own lives, we see that Justice Higgins was really claiming for himself the right to decree the terms on which suppliers (that is, workers) were able to offer their services. The coercive and immoral consequences of this approach are with us today. Johnston (1993) reports that in November 1993 the Maritime Union of Australia fined nine workers from Australian Stevedores for an offence in which, according to the workers involved, 'instead of taking their time, they got in and got things done'. The union's defence of the fine was that the employer had 'coerced' the men into working in this manner: as if no coercion were involved in the collection of the fine!

\section{The Unequal Bargaining Power Argument}

The textbook treatment of markets assumes many buyers and sellers, none of whom individually has any impact on the market outcome. It is often claimed that many labour markets are in fact dominated by large employers, or at least would be so dominated if it were not for the 'countervailing power' exercised by monopoly labour unions. The conditions allowing a firm to exercise power in the labour market are, however, far more stringent than is generally supposed. It is not suffcient for the firm to employ many people, although this makes it look 'large' relative to the employee. The employer must be the sole demander of a particular type of labour, or must collude with all other potential employers to prevent them from 'poaching' his underpaid workers. Unless these conditions are satisfied, the fact that an employer is large relative to an individual employee says nothing about the relative amount of market power these parties exercise.

Clearly, there are cases where a single employer is dominant over a geographical area and hence exercises some potential market power. On the other hand, in many such cases the employer is equally reliant on the 'isolated' workforce. This is in part what allows workers in remote areas to use the strike threat in order to extract high wages and/or luxurious working conditions. More generally, the key problem of market concentration and collusion is far more severe in markets other than that for labour and is the concern of trade-practices law. Labour is not unique in having 'size' imbalances between buyer and seller; in fact, it is characterised by 
relatively mild problems of market power. ${ }^{1}$ Moreover, where market power is detected, the appropriate response is to support or enhance competition, not to compound the problem by enforcing monopoly unionism on the other side of the market.

\section{The Ignorance Argument}

A related concern is not that employers actually collude but that potential employees do not have sufficient information to use the bargaining power they possess. Isaac (1982:499) claims that 'real people often behave irrationally in economic terms because they lack the information to behave otherwise'.

It is true that no one makes decisions with complete knowledge of all available alternatives. But it is a huge leap to conclude that this causes people to behave in a way that is counter to their interests (this is what it really means to 'behave irrationally in economic terms'), since decision makers have every incentive both to recognise gaps in their knowledge and to take steps to fill them. An employee who relies on a false representation by his employer bears the full cost of this naivety. To be sure, choosing a job is far more demanding than choosing a cabbage. But this added complexity increases the importance of allowing the individuals involved to choose for themselves. Although a member of the Industrial Relations Commission might be able to select an appropriate cabbage for most people, none is able to select an appropriate job. Of course, this argument unfairly understates the difficulties and complexities involved in producing and distributing cabbages. Citizens of centralised economies, past and present, have been notably deprived of such 'commodities'.

\section{The Authority Argument}

One further feature of the employment relationship may give the impression of unequal bargaining power. This is the fact that, in many workplaces, employees are to some degree subject to the directions of their supervisors and managers. Indeed, as Masten (1988) argues, a key distinction between the independent contractor and the employer/employee relationships is that the employee agrees to obey a (limited) set of directives from his employer. But this 'managerial prerogative' to direct the manner of work does not in any way suggest the oppression of employees by employers. It is simply an efficient way to organise production in some circumstances (see Garvey, 1993 for details and references on the efficiency attributes of authority arrangements). Employees voluntarily agree to work under these conditions. It is also a delusion to claim that they do so only because they have 'no choice'. If employees find the exercise of managerial prerogative to be irksome, they will receive

\footnotetext{
${ }^{1}$ Ironically, some of the excess profits that large firms are able to make at consumers' expense seem, in practice, to accrue to the employees of the seller. This linkage was explicit in the Australian policy of granting of tariff protection to allow employers to pay high wages; but it is also observed in the US and elsewhere (Krueger \& Summers, 1988).
} 
higher remuneration than for equivalent jobs offering greater personal autonomy. In this way, the cost of exercising authority over employees is borne by employers, a fact that is reflected in many recent employer-led drives to allow greater autonomy and ownership for their employees.

\section{Minimum Standards to 'Protect the Weak'}

A number of labour-market policies are based on arguments for the uniqueness of labour. The distinction between labour and other 'commodities' sometimes represents a justifiable (and provisional) simplification that serves to facilitate analysis of specific markets. But it is more often invoked to banish economic reasoning from the labour-market policy debate. For example, mandated minimum prices or conditions are no longer seriously defended as a way to help wool growers or landlords. The perverse side-effects of rent control and wool-price floors are widely recognised: outright physical waste such as decaying buildings and unused wool-stocks, and serious additional hardships for poorer tenants and for wool farmers. Only by asserting that labour is fundamentally different can one defend our comprehensive system of minimum wages and conditions. In fact, low prices in each case reflect the fundamentals of supply and demand: wool growers cannot prosper when the price for their good falls, nor can workers whose current stock of skills is not in high demand. Australia's labour-market policies even make it illegal for workers to enhance their skills through on-the job training (see Boot, 1992, for further discussion of the training issue).

The recent Green Paper on unemployment (Committee on Employment Opportunities, 1993) espouses the belief that labour is different in a way that justifies mandatory minimum standards. Chapman (1994) argues that the New Zealand case demonstrates that deregulation of conditions is not the way to help the longterm unemployed. But, as Brook (1991) pointed out even before the New Zealand Employment Contracts Act came into force, minimum wages and conditions of employment were not removed, but have continued to curtail the job and training opportunities of those whose current stock of skills would place them in the 'lowpaid' category. And, consistent with basic economic theory, these people have not been much helped by economic recovery.

\section{Using Labour Market Policy to Encourage Specific Outcomes}

The business press has for some time been preoccupied with the idea that we are entering a new era featuring employee empowerment, total quality management, better employee relations, decentralisation, and devolution of authority, to name just a few of the current buzz-words. The Business Council of Australia (1990) has argued that the new world of global business requires enterprise bargaining and representation at the enterprise level. This may encourage lead unions to be more responsive to the demands of their members and their employers. But, as Brook (1991) points out, it simply replaces one form of mandated structure with another 
that is more attractive to business. Enterprise bargaining may not be the optimal way for some employer/employee pairs to conduct their affairs, and there is no gain to mandating such structures. Indeed, the central goal of introducing enterprisebased employee relations seems to be to ensure that no workplace has more than one union representing its workers (see especially Hilmer, 1993). Although this is probably a sensible arrangement in many cases, such a structure would emerge quite naturally in a system where employees were free to choose the sort of representation they wish. Labour-market efficiency and fundamental human rights for sellers of labour require freedom of contract and representation, not a new mandated structure. ${ }^{2}$

\section{Conclusions}

It is a common delusion to treat people's choice to sell their labour as fundamentally different from other economic choices they might take. Every market interaction involves people seeking to enhance their own personal ends (which can easily include charity and altruism as well as concern for one's own immediate family). The exchange of labour services certainly involves a great deal of uncertainty and open-ended commitment by both buyer (employer) and seller. As with the purchase of many complex goods, there is more to effecting mutually gainful exchange than merely exchanging a good for money. Far more sophisticated contractual arrangements are called for. But the parties involved have every incentive to choose the appropriate set of arrangements and safeguards (see Garvey, 1994, for a more detailed discussion). The appropriate set of safeguards might well include labour unions where there is a demand for such organisations to support rather than impede exchange. Indeed, some New Zealand unions have been increasing their membership since the Employment Contracts Act 1991 relaxed their monopoly hold over workers (Boxall \& Haynes, 1992; Kiely \& Caisley, 1992). Some other unions whose role in the labour contracting was less benign did lose membership.

Labour is not different from other commodities in any economic or moral respect that removes it from the scope of conventional economic analysis. Workers are not well served by a system that restricts their freedom to engage employers on mutually acceptable terms. Individual employers and employees are the parties who can best manage the complexities encountered in exchanging labour services and developing human capital. Since unions and other 'collectivist' aspects of the labour relationship will be chosen where appropriate, there is no case for mandating them.

\footnotetext{
${ }^{2}$ Matthews (1992) argues that mandated minimum standards are required to ensure that businesses prosper in the world of the globally competitive, total-quality managed business. This argument rests on the bizarre premise that low-quality products will out-compete high-quality ones. But the argument is no more bizarre than the one implicit in the Business Council of Australia's advocacy of enterprise unions, namely, that companies will forgo the high profits they could allegedly realise by shifting to enterprise unions.
} 


\section{References}

Boot, H. (1992), 'Training, Wages and Human Capital', Policy 8(3): 13-17.

Boxall, P. \& P. Haynes (1992), 'Unions and Non-Union Bargaining Agents under the ECA 1991', New Zealand Joumal of Industrial Relations 17: 223-32.

Brook, P. (1990), Freedom at Work: The Case For Reforming Labour Law in New Zealand, Oxford University Press, Auckland.

- (1991), 'New Zealand's Employment Contract Act: An Incomplete Revolution', Policy 7(3): 610.

Business Council of Australia (1989), Enterprise-Based Units: A Better Way of Working, Melbourne.

Chapman, B. (1994), 'Helping the Long-Term Unemployed', The Canberra Times, 3 January: 9.

Committee on Employment Opportunities (1993), Restoring Full Employment, AGPS, Canberra.

Garvey, G. (1993), 'Does Hierarchical Governance Facilitate Adaptation to Changed Circumstances?', Joumal of Economic Behaviour and Organization 20: 187-211.

- (1994), The Market for Employment, Centre for Independent Studies, Sydney.

Hilmer, F. (1993), Working Relations: A Fresh Start for Australian Enterprises, Business Council of Australia, Melbourne.

Isaac, J. (1982), 'Economics and Industrial Relations', Journal of Industrial Relations 24: 495-520.

Johnston, N. (1993), 'Union Fines Men for Working Too Hard', Sydney Morning Herald, 29 November: 1 .

Kiely, R. \& S. Caisley (1992), 'One Year of Practise with the Act', New Zealand Journal of Industrial Relations 17: 233-41.

Krueger, A. \& L. Summers (1988), 'Efficiency Wages and the Intra-Industry Wage Structure', Econometrica 56: 259-93.

Masten, S. (1988), 'A Legal Basis for the Firm', Journal of Law, Economics, and Onganization 4: 18198.

Matthews, J. (1992), 'Competitive Edge is On the Line', Australian Financial Review, 21 October: 12.

McCallum, R. (1993), Review of P. Brook, Freedom at Work The Case for Reforming Labour Law in New Zealand, Australian Jounal of Labour Law 5: 295-99.

Shann, E. (1930) An Economic History of Australia, Cambridge University Press, Cambridge, Ma.

Sloan, J. (1994), 'Labouring over Economics', Australian Financial Review, 7 January: 17. 